\title{
The Role of Leadership Styles and Motivation on Teacher Performance
}

\author{
Sahara Indah Sutrisni*, Endi Sarwoko \\ Magister Management Study Program \\ Universitas PGRI Kanjuruhan Malang \\ Malang, Indonesia \\ *sahararais.scout72@gmail.com,endiswk@unikama.ac.id
}

\begin{abstract}
Teacher performance is an important factor in improving the quality of education in general. Therefore, teacher performance needs to receive attention from schools, by paying attention to factors related to teacher performance such as principal leadership and work motivation. This study aims to investigate the role of leadership style and work motivation on teacher performance. This study used a quantitative approach, using a questionnaire to collect data. The sample of the study was 180 Islamic Senior High School teachers in Malang Regency, taken using a proportional random sampling technique. The data analysis technique used was the Multiple Linear Regression. The results showed that teacher motivation had a positive and significant effect on teacher performance, the higher the teacher's motivation might increase their performance. This study also found that leadership style had a positive and significant effect on teacher performance. Strong leadership was able to direct member behavior to achieve performance improvement. However, this study cannot be generalized since this study was only conducted at private schools in Malang Regency. Further studies are recommended to use a wider sample. Besides, the performance appraisal was based on the subjective measurement of the respondent. Thus, there is a possibility of bias.
\end{abstract}

\section{Keywords-leadership, work motivation, teacher performance}

\section{INTRODUCTION}

In recent years, public interest in and recognition of schools based on Islamic religious education has increased [1]. Thus, schools based on Islamic religious education are no longer the second option for parents in admitting their children. Parents have set their children's preferences or priorities to be able to enter Islamic-based education schools to continue their studies indicating that Islamic-based schools are not inferior to public schools [2]. One of the factors that determine the quality of school education is the leadership and performance of human resources. The teacher as an important resource in schools will determine the achievement of learning objectives. Therefore, teacher performance might be the key to the successful management of education in schools. Leadership in an organization can increase satisfaction and positively affect the performance of subordinates [3]. Accordingly, leadership will motivate subordinates, build trust in a relationship, and encourage creativity [4], since employee performance is influenced by employee work motivation [5].

Previous studies have explained that leadership has a positive effect on performance [6-8]. Leadership needs attention for it might improve performance [9]. Specifically, transformational leadership is a style that affects performance $[10,11]$. Democratic leadership style has a positive impact on employee performance [12], while a participatory leadership style affects teacher performance [13]. Thus, leadership plays a role in directing the behavior of organizational members. It aims to achieve individual performance that will support the achievement of organizational goals.

Although research has acknowledged the role of leadership on performance, there is a debate about the role of leadership on performance, where other findings suggest that leadership does not affect performance [14-16]. More specifically, servant leadership and transformational leadership do not affect performance $[17,18]$. Therefore, it is necessary to further investigate the effect of leadership on performance. In this case, a study was developed with the motivation variable as a factor that determines performance. This is based on the fact that work motivation will affect teacher performance, the higher work motivation will be followed by good teacher performance $[19,20]$. This study aims to investigate the effects of school leadership and work motivation on teacher performance.

\section{A. Leadership and Performance}

Leadership is an activity to direct the behavior of subordinates to achieve the expected performance [21]. The leader's job is to carry out management functions, enable leadership cannot be separated from management, the focus of leadership is how the organization copes with change [22]. Path-Goal theory states that leaders use different behaviors for different subordinates and conditions, depending on the subordinates and the situation. Leadership will increase motivation and performance [23]. This study employed three types of leadership behavior, namely directive, supportive, and participatory [22]. 
1) Directive: The leader directs subordinates about the tasks that have to be done, including the expected results, as well as the time to complete certain tasks. Therefore there are performance standards and clear rules [24]. Directive behavior is well-suited for complex types of tasks and requires strong authority.

2) Supportive: Leadership is close to subordinates, care about their welfare and needs, and are friendly [24]. Appropriate supportive behavior is best suited for simple tasks, where formal authority is weak.

3) Participatory: Leaders involve subordinates in making decisions, to get their input and opinions [24]. Participatory behavior is very suitable for complex types of tasks but subordinates have high abilities.

Previous studies have tested that leadership in schools is a factor affecting teacher performance $[6,13,25,26]$. Leadership is an important variable that needs high attention to improve teacher performance [9]. Furthermore, more specific research related to leadership styles shows that transformational leadership styles might help subordinates to achieve organizational goals and mission by working together with them [11], contributing to performance or outcomes [10]. Likewise, employee performance will increase when democratic leadership is applied [12]. Leadership style becomes a management tool to improve positive relationships with employees, improve organizational climate, and improve performance [27].

H1: The leadership styles has a positive effect on performance

\section{B. Work Motivation and Performance}

McClelland's theory of motivation states a person's motivation is based on three basic needs, namely Need for Achievement, Power, and Affiliation [28].

1) Need for Achievement (nAch): The Need for Achievement theory explains that motivation and performance will vary according to the level of a person's need for achievement. The need for achievement is the need to do something better, complete a difficult task, and overcome obstacles [29]. Individuals who have a high need for achievement will tend to value high performance, are conscientious, and set challenging goals for themselves [30].

2) Need for Affiliation (nAff): Someone who has a high need for affiliation will enjoy being with other people and feel involved in the group [29]. People with a high need for affiliation are friendly people who will strive to maintain social relationships and are confident in the ability to work in teams [30].

3) Need for Power (nPow): The need for power is the desire to feel strong, control others [29], influence others, and encourage others to achieve [30]. Motivation plays an important role in achieving organizational goals [31], for high motivation will encourage employee responsibility in completing their work [32] to increase performance achievement [33,34]. Employees who have high work motivation might do their best for the progress of an organization and play a role in improving employee performance [26], since the higher work motivation might be followed by a good teacher performance $[35,36]$.

$\mathrm{H} 2$ : Work motivation has a positive effect on performance.

\section{METHODS}

This study employed a quantitative research approach, using a questionnaire to 180 Islamic senior high school teachers in Malang Regency as the research sample. The research variables consisted of leadership style and motivation as independent variables and teacher performance as the dependent variable. Leadership style was measured using indicators: directive, supportive, and participatory leadership (12 items). Teacher work motivation was measured by three indicators, namely the need for achievement, affiliation, and power (12 items). Teacher performance was measured by indicators of work quality, work quantity, and punctuality (6 items). All indicators were measured using a 5-point Likert scale, ranging from positive responses (score 5) to negative responses (score 1).

The validity test of the questionnaire for leadership style, work motivation, and performance was done using the corrected item-total correlation technique. Moreover, all items sued have met the validity criteria. The reliability of the questionnaire was calculated using the Cronbach's Alpha method, and the questionnaire met the criteria for reliability with the result that the value of Cronbach's Alpha for the leadership of 0.781 , work motivation of 0.776 , and performance of 0.784 . Furthermore, descriptive statistical analysis and Simple Linear Regression were carried out for hypothesis testing. The obtained data were then analyzed using SPSS software.

\section{RESULTS AND DISCUSSION}

\section{A. Descriptive Statistics}

Descriptive statistics presented in Table 1 describe the results of measuring leadership style, work motivation, and performance based on the data collected using a questionnaire.

TABLE I. DESCRIPTIVE STATISTICS

\begin{tabular}{|c|c|c|}
\hline Variable and Indicator & Mean & Stdev \\
\hline Leadership & $\mathbf{4 . 1 2 1 3}$ & $\boldsymbol{0 . 6 7 7 1 4}$ \\
\hline Directive & 4.1750 & 0.74884 \\
\hline Supportive & 4.0688 & 0.76097 \\
\hline Participatory & 4.1187 & 0.70259 \\
\hline Motivation & $\mathbf{3 . 8 8 8 1}$ & $\boldsymbol{0 . 7 3 7 0 2}$ \\
\hline Need for achievement & 4.1812 & 0.60845 \\
\hline Need for affiliation & 4.0344 & 0.79828 \\
\hline Need for power & 3.4469 & 1.10715 \\
\hline Performance & $\mathbf{4 . 3 0 9 9}$ & $\mathbf{0 . 5 4 1 4 8}$ \\
\hline Work quality & 4.3125 & 0.64325 \\
\hline Work quantity & 4.3937 & 0.62487 \\
\hline Punctuality & 4.2250 & 0.67926 \\
\hline
\end{tabular}


The measurement results of the leadership style, work motivation, and teacher performance in Table 1 show that the school principal applied directive, supportive, and practical leadership, where directive and participatory leadership dominated more than supportive leadership. Meanwhile, the measurement of work motivation shows that teachers had high work motivation with an average of 3.89 (range 1 to 5) supported by the fulfillment of the needs for performance and the needs for affiliation. Meanwhile, the need for power was sufficient.

Teacher performance measurement shows that teachers had a high performance with an average of 4.31 (range 1 to 5). This was supported by good work results in terms of quality, quantity, and punctuality.

\section{B. Hypothesis Testing}

Table 2 describes the results of the Multiple Linear Regression analysis between leadership style and work motivation on teacher performance.

TABLE II. HYPOTHESIS TESTING

\begin{tabular}{|l|l|l|l|}
\hline \multicolumn{1}{|c|}{ Variable } & \multicolumn{1}{c|}{ B } & \multicolumn{1}{c|}{ Sig. } & Result \\
\hline Leadership style & 0.276 & $0.001^{*}$ & Support \\
\hline Motivation & 0.271 & $0.001^{*}$ & Support \\
\hline
\end{tabular}

The results of the analysis in Table 2 show the leadership style coefficient, $\beta 1=0.764$ (sig. 0.05), indicating that leadership style had a positive and significant effect on teacher performance. Thus, $\mathrm{H} 1$ is supported. This finding explains that the principal leadership style direct teacher behavior to achieve the expected performance. The results of this study support previous research that leadership might have a positive impact on performance [7-9]. Leadership style can improve teacher performance for good leadership has directive abilities, the ability to direct human resources to achieve individual and organizational goals. Furthermore, good leadership has supportive abilities or can provide support for any teacher problems in completing assignments. Leadership is required to be participatory, directly involved with teachers to achieve school goals. If supportive and directive abilities are applied in the leadership style of the principal, they might affect the achievement of teacher performance.

The motivation coefficient, $\beta 2=0,546$ ( $\mathrm{sig}$. 0.00), shows that work motivation had a positive and significant effect on teacher performance. Thus, $\mathrm{H} 2$ is supported. These findings explain that the higher the teacher's work motivation might have an impact on improving their performance. The results of this study support previous studies that work motivation affect performance [5,30,35]. Motivation is a drive that comes from within and from outside a person. Intrinsic motivation includes the need for achievement, the need for affiliation, and the need for power. If these needs are met, the teacher can achieve high performance for their needs have been met for their work.

\section{CONCLUSION}

This study aims to investigate the effects of leadership style and work motivation on teacher performance. The results showed that the principal's leadership had a positive and significant effect on teacher performance. The implementation of the directive, supportive, and participatory leadership by the principal can improve teacher performance. Teacher work motivation had a positive and significant effect on teacher performance. The more fulfilled the need for achievement, the need for affiliation, and the need for power might cause teachers to be more motivated and might improve their performance.

This study has limitations for this was only conducted in one school. Thus, the generalization level is low. Furthermore, performance measurement was carried out by self-assessment. Thus, there was a chance for bias. Future studies are advised to expand the research to several organizations/schools to reduce bias and to use the results of teachers that have been done by the school.

\section{REFERENCES}

[1] S.I.T. Suyatno and I. Filsafat, "Tren Baru Pendidikan Islam di Indonesia," J. Pendidik. Islam, vol. 2, 2013.

[2] R. Solihin and A.R. Fauzi, "Penurunan Minat bersekolah di SD Neger dibandingkan SD Islam: Studi Kasus di Kecamatan Garum Kabupaten Blitar," Briliant J. Ris. dan Konseptual, vol. 2, no. 3, pp. 392-401, 2017.

[3] R.-E. Hurduzeu, "The impact of leadership on organizational performance," SEA-Practical Appl. Sci., vol. 3, no. 07, pp. 289-293, 2015.

[4] I. Naile and J.M. Selesho, "The role of leadership in employee motivation,” Mediterr. J. Soc. Sci., vol. 5, no. 3, pp. 175-182, 2014.

[5] J.E. Barbuto and G.T. Gifford, "Motivation and leader-member exchange: Evidence counter to similarity attraction theory," Int. J. Leadersh. Stud., vol. 7, no. 1, pp. 18-28, 2012.

[6] S. Nuraisyah, "Pengaruh Kepemimpinan Kepala Sekolah, Budaya Organisasi Dan Motivasi Kerja Guru Terhadap Kinerja Guru Pada SMP Negeri Di Kecamatan Pandan Kabupaten Tapanuli Tengah Sumatera Utara," J. Bisnis dan Manaj., vol. 1, no. 1, 2014

[7] H.S.R. Sawitri, "Pengaruh Gaya Kepemimpinan dan Budaya Organisas pada Kinerja Guru dengan Motivasi Sebagai Variabel Intervening," J. Bisnis dan Manaj., vol. 16, no. 1, pp. 43-54, 2017

[8] E.T. Putra and Y. Yunita, "Pengaruh Kepemimpinan Kepala Sekolah dan Budaya Organisasi terhadap Kinerja Guru SMA Negeri 1 Simpang Empat," J. Apresiasi Ekon., vol. 2, no. 3, pp. 143-152, 2014

[9] B.D. Hartono and Zubaidah, "The Influence Of Leadership, Organizational Culture And Work Discipline On Teacher Performance Regarding Work Motivation As Interverning Variable (A Case Study Of Yayasan Pendidikan Pondok Pesantren Al Kholidin)," Int. J. Econ. Bus. Manag. Res., vol. 1, no. 01, pp. 69-95, 2017.

[10] M. Asrar-ul-Haq and K.P. Kuchinke, "Impact of leadership styles on employees' attitude towards their leader and performance: Empirical evidence from Pakistani banks," Futur. Bus. J., vol. 2, no. 1, pp. 54-64, 2016

[11] A. Tajasom, D.K.M. Hung, D. Nikbin, and S.S. Hyun, "The role of transformational leadership in innovation performance of Malaysian SMEs," Asian J. Technol. Innov., vol. 23, no. 2, pp. 172-188, 2015.

[12] A. Basit, V. Sebastian, and Z. Hassan, "Impact of Leadership style on Employee Performance (a case study on a private organization in 
Malaysia)," Int. J. Account. Bus. Manag., vol. 5, no. 2, pp. 112-130, 2017.

[13] T. Handayani and A.A. Rasyid, "Pengaruh Kepemimpinan Kepala Sekolah, Motivasi Guru, Dan Budaya Organisasi Terhadap Kinerja Guru Sma Negeri Wonosobo,” J. Akuntabilitas Manaj. Pendidik., vol. 3, no. 2, pp. 264-277, 2015.

[14] U.T. Cahyono, M.S. Maarif, and S. Suharjono, "Pengaruh kepemimpinan transformasional terhadap kinerja karyawan di perusahaan daerah perkebunan jember," J. Manaj. Agribisnis, vol. 11, no. 2, pp. 68-76, 2014.

[15] K.S.K. Elgelal and N. Noermijati, "The influences of transformational leaderships on employees performance (A study of the economics and business faculty employee at University of Muhammadiyah Malang)," APMBA (Asia Pacific Manag. Bus. Appl., vol. 3, no. 1, pp. 48-66, 2015.

[16] C.O. Posuma, "Kompetensi, kompensasi, dan kepemimpinan pengaruhnya terhadap kinerja karyawan pada Rumah Sakit Ratumbuysang Manado," J. EMBA J. Ris. Ekon. Manajemen, Bisnis dan Akunt., vol. 1, no. 4, 2013.

[17] M. Darto, D. Setyadi, S.S. Riadi, and S. Hariyadi, "The effect of transformational leadership, religiosity, job satisfaction, and organizational culture on organizational citizenship behavior and employee performance in the regional offices of national institute of public administration, Republic of Indone,” Eur. J. Bus. Manag., vol. 7, no. 23 , pp. 205-219, 2015

[18] S. Sihombing, E.S. Astuti, M. Al Musadieq, D. Hamied, and K. Rahardjo, "The effect of servant leadership on rewards, organizational culture and its implication for employee's performance," Int. J. Law Manag., 2018.

[19] S. Andriani, N. Kesumawati, and M. Kristiawan, "The influence of the transformational leadership and work motivation on teachers performance," Int. J. Sci. Technol. Res., vol. 7, no. 7, pp. 19-29, 2018.

[20] D.U. Wahyuni, B. Christiananta, and A. Eliyana, "Influence of Organizational Commitment, Transactional Leadership, and Servant Leadership to the Work Motivation, Work Satisfaction and Work Performance of Teachers at Private Senior High Schools in Surabaya," Educ. Res. Int., vol. 3, no. 2, pp. 82-96, 2014.

[21] J.P.J. De Jong and D.N. Den Hartog, "How leaders influence employees' innovative behaviour," Eur. J. Innov. Manag., 2007.

[22] S.P. Robbins and T.A. Judge, Perilaku organisasi. Jakarta: Salemba Empat, 2015.

[23] S.H. Malik, "Relationship between leader behaviors and employees' job satisfaction: A path-goal approach," Pakistan J. Commer. Soc. Sci., vol. 7, no. 1, pp. 209-222, 2013

[24] P.G. Northouse, Leadership: Theory and practice. US: Sage publications, 2018.
[25] M.J. Syakir and P. Pardjono, "Pengaruh Kepemimpinan Kepala Sekolah, Motivasi Kerja, Dan Budaya Organisasi Terhadap Kompetensi Guru Sma," J. Akuntabilitas Manaj. Pendidik., vol. 3, no. 2, pp. 226-240, 2015

[26] D.S. Widodo, "Pengaruh Budaya Organisasi, Kepemimpinan Dan Kompensasi Melalui Motivasi Kerja Terhadap Kinerja Pegawai,” J. Manaj. Motiv., vol. 13, no. 2, pp. 896-908, 2017.

[27] M.A. Kozak and S. Uca, "Effective factors in the constitution of leadership styles: A study of Turkish hotel managers," Anatolia, vol. 19, no. 1, pp. 117-134, 2008.

[28] S.D. Jager, M. Born, and H. Van der Molen, "Self-other agreement between employees on their need for achievement, power, and affiliation: A social relations study," Scand. J. Work. Environ. Heal., vol. 2, no. 9, pp. 1-12, 2017.

[29] T. Bipp and K. van Dam, "Extending hierarchical achievement motivation models: The role of motivational needs for achievement goals and academic performance," Pers. Individ. Dif., vol. 64, pp. 157$162,2014$.

[30] S. Jha, "Need for growth, achievement, power and affiliation: Determinants of psychological empowerment," Glob. Bus. Rev., vol. 11, no. 3, pp. 379-393, 2010.

[31] A. Ali, L.Z. Bin, H.J. Piang, and Z. Ali, "The Impact of Motivation on the Employee Performance and Job Satisfaction in IT Park (Software House) Sector of Peshawar, Pakistan,” Int. J. Acad. Res. Bus. Soc. Sci., vol. 6, no. 9, pp. 297-310, 2016.

[32] M. Azar and A.A. Shafighi, "The effect of work motivation on employees' job performance (Case study: employees of Isfahan Islamic Revolution Housing Foundation),” Int. J. Acad. Res. Bus. Soc. Sci., vol. 3 , no. 9, p. 432, 2013

[33] A.A.B.W. Putra, "Pengaruh kepemimpinan, motivasi dan lingkungan kerja fisik terhadap kinerja karyawan pada Bank Pembangunan Daerah (BPD) Bali Cabang Utama Denpasar," JSAM (Jurnal Sains, Akunt. dan Manajemen), vol. 1, no. 4, pp. 609-625, 2019.

[34] E. Widyawatiningrum, U. Suryadi, and R. Rizal, "Pengaruh Motivasi, Kepemimpinan, Budaya Organisasi Terhadap Kinerja Dengan Kepuasan Sebagai Variabel Intervening di PTPN X Jember," J. Teknol. Pertan., vol. 16, no. 2, pp. 127-136, 2015.

[35] S. Andriani, N. Kesumawati, and M. Kristiawan, "The Influence of the Transformational Leadership and Work Motivation on Teachers Performance,” Int. J. Sci. Technol. Res., vol. 7, no. 7, pp. 19-29, 2018.

[36] M.N. Hasan, "Influence of Work Motivation , Leadership and Organizational Culture Principal of the Teacher Performance in Vocational School ( SMK ) Muhammadiyah, Rembang City, Central Java Province, Indonesia,” Eur. J. Bus. Manag., vol. 9, no. 2, pp. 36-44, 2017 